\title{
Behavior, health, and productivity of early-lactation dairy cows supplemented with molasses in automated milking systems
}

\author{
S. M. Moore, M. T. M. King, (1) A. J. Carpenter, (1) and T. J. DeVries* (1) \\ Department of Animal Biosciences, University of Guelph, 50 Stone Rd. East, Guelph, ON, N1G 2W1, Canada
}

\begin{abstract}
The objective of this study was to determine the effect of molasses-based liquid feed (LF) supplementation within automated milking systems (AMS) on the behavior, health, and production of early-lactation dairy cows. In 6 commercial AMS dairy herds, 390 dairy cows were randomly assigned before calving to 1 of 2 treatments, within farm, balanced by parity: (1) control group $(\mathrm{CON})$ receiving a standard AMS pellet [mean $=3.9 \mathrm{~kg} / \mathrm{d}$ on a dry matter $(\mathrm{DM})$ basis, $\mathrm{n}=188]$, or (2) same amount of standard AMS pellet (mean $=3.6$ $\mathrm{kg} / \mathrm{d}$ on a DM basis, $\mathrm{n}=202$ ) plus $1 \mathrm{~kg} / \mathrm{d}$ DM of LF for multiparous cows $(1.6 \mathrm{~kg} / \mathrm{d}$ as fed) and $0.88 \mathrm{~kg} / \mathrm{d}$ DM for primiparous cows $(1.4 \mathrm{~kg} / \mathrm{d}$ as fed). Across farms, cows were fed partial mixed rations similar in ingredient and nutrient composition. Cows on the LF treatment received supplementation for the first $60 \mathrm{~d}$ in milk (DIM). Blood samples were taken 2 times/wk for the first $3 \mathrm{wk}$ postcalving to assess $\beta$-hydroxybutyrate (BHB). Samples with BHB $\geq 1.2 \mathrm{mmol} / \mathrm{L}$ were classified as a positive case of subclinical ketosis (SCK). Cow body condition and lameness were scored every $10 \mathrm{~d}$ postcalving until 60 DIM. No differences were detected between treatments for milk yield (average milk yield $=37.4 \pm 1.98 \mathrm{~kg} / \mathrm{d}$ ) and milking frequency (average milking frequency $=3.2 \pm 0.01$ times/d). Similarly, no difference between treatments in daily AMS visits was detected (average AMS visits $=5.3 \pm 0.3$ times/d). However, CON cows experienced more AMS refusals/d than $\mathrm{LF}$ cows $(\mathrm{LF}=1.6$ refusals $/ \mathrm{d}, \mathrm{CON}=2.1$ refusals/d). No difference between treatments in daily rumination time was detected (average rumination time $=476 \pm 10.8 \mathrm{~min} / \mathrm{d}$ ). Treatment was associated with the number of times cows tested positive for SCK; cows on LF had fewer repeated diagnoses of SCK, such that $15 \%$ of cows on LF had $\geq 3$ diagnoses of SCK out of 5 tests, compared with $27 \%$ of CON cows. Cows receiving molasses tended to have lower blood BHB values
\end{abstract}

Received April 3, 2020.

Accepted June 25, 2020.

*Corresponding author: tdevries@uoguelph.ca at $\sim 15$ DIM. Molasses supplementation also allowed cows to maintain a more stable body condition score, as LF cows tended to lose less body condition over the first 60 DIM compared with CON cows. Overall, the results of this study demonstrate that supplementing a molasses-based LF to AMS cows may help support the energy demands of milk production in early lactation and, thus, reduce the incidence of repeat positive SCK tests during that time period.

Key words: molasses, sugar, robotic milking systems, subclinical ketosis

\section{INTRODUCTION}

Automated (robotic) milking systems (AMS) have been adopted within the dairy industry at an exponential rate, worldwide, since the first commercial system was started in 1992 (de Koning, 2011). Globally, more than 35,000 farms were estimated to be milking cows with AMS as of 2014 (Salfer et al., 2017). These systems provide a unique opportunity to manage cows at the individual level, both in terms of milking frequency and supplemental feeding at the AMS (Bach and Cabrera, 2017). Individualized milking allows for more frequent milking than conventional systems (Wagner-Storch and Palmer, 2003); this may increase milk yield, but may also be associated with greater risk of negative energy balance (NEB; Tatone et al., 2017). In a recent study in Ontario, Canada, the herd-level prevalence of subclinical ketosis (SCK), as measured through milk ketone levels, was reported to be greater for AMS herds $(26 \%)$ compared with conventionally milked herds (21\%; Tatone et al., 2017). Additionally, Tatone et al. (2017) reported that multiparous cows in AMS herds were more likely to have SCK than multiparous cows in conventional herds. Furthermore, researchers have reported that development of SCK in commercial AMS-milked cows was associated with greater production of milk relative to the amount of feed provided in the AMS during the first week postcalving (King et al., 2018), suggesting that inadequate supplementation at that time may be a contributing factor to the observed SCK. 
Commonly, in early lactation, the quantity and type of feeds offered to cows are modified in an attempt to support the energy demands observed at that time. However, these feeds are commonly greater in energy and starch, and lesser in forage and fiber (McCarthy et al., 2015). In AMS farms, greater supplementation of traditional, high-starch AMS concentrates in early lactation may be problematic due to increased risk of depressed rumen $\mathrm{pH}$ (i.e., SARA; Bach and Cabrera, 2017). Feeding sugar sources, as opposed to starch, however, has the potential to provide energy without increasing the risk of SARA (Oba, 2011; de Ondarza et al., 2017). Limited research is available on the benefits of feeding dietary sugar, as opposed to starch, to cows during early lactation. Penner and Oba (2009) reported that replacing cracked corn with a dietary sugar (sucrose) improved rumen health, DMI, and milk production. Similarly, in past research it has been demonstrated that feeding cows a molasses-based liquid feed (a highly concentrated sugar supplement) within a TMR has the ability to increase DMI, milk yield, and component yields of lactating cows (DeVries and Gill, 2012). Sugar supplementation supports microbial growth, particularly for fiber-digesting bacteria, speeding up fiber degradation and allowing for greater intake (de Ondarza et al., 2017); this in turn may help improve energy balance. Despite the worldwide exponential increase in AMS, to our knowledge, no previous studies have been conducted to investigate the effects of supplementing sugar to early-lactation cows in AMS, where energy demands may be greater compared with conventional milking herds (Tatone et al., 2017; King et al., 2018).

The objective of this study was to determine the effect of molasses-based liquid feed supplementation to early-lactation cows in AMS on behavior, health, and productivity. We hypothesized that supplementation of molasses, in addition to AMS concentrate provision, to early-lactation cows would improve their energy balance postcalving, while increasing their milking frequency and milk production.

\section{MATERIALS AND METHODS}

\section{Animals and Housing}

A study was conducted where we enrolled 390 dairy cows, including 124 primiparous and 279 multiparous (parity $=3.1 \pm 1.35$, mean $\pm \mathrm{SD}$ ), from 6 commercial AMS herds (Table 1) in southwestern Ontario (Canada) and followed them for their first 60 DIM. The use of cows and experimental procedures complied with the guidelines of the Canadian Council on Animal Care (2009) and were approved by the University of Guelph Animal Care Committee (AUP \#3964). Before study enrollment, the health status of each cow was evaluated and cows having experienced serious health concerns (e.g., severe lameness/hock or leg injuries, milk fever) during the close-up dry period or around the time of calving were excluded from the study. Similarly, cows were removed from the study at the discretion of the producer or herd veterinarian (or both) if serious health illnesses developed during the duration of the trial or if the cow was unable to visit the AMS for prolonged periods of time; these cows were not included in our total enrolled cows.

All cows were dried off $\sim 60 \mathrm{~d}$ before calving. All farms fed a single dry cow diet $60 \mathrm{~d}$ before calving, with the exception of one farm that also fed a far-off dry cow diet and switched to a close-up dry cow diet $21 \mathrm{~d}$ be-

Table 1. Number of automated milking systems (AMS), cows enrolled, and average milk yield and frequency ${ }^{1}$ by parity ${ }^{2}$ and treatment ${ }^{3}$ by farm (1-6)

\begin{tabular}{lrrrrrr}
\hline Farm & 1 & 2 & $3^{4}$ & 4 & 5 & 6 \\
\hline Number of AMS per farm & 4 & 4 & 1 & 3 & 2 & 2 \\
Total number of cows enrolled & 106 & 109 & 24 & 78 & 45 & 28 \\
Number of PPS control cows & 15 & 18 & 0 & 10 & 9 & 3 \\
Number of MPS control cows & 36 & 36 & 15 & 26 & 12 & 8 \\
Number of PPS liquid feed cows & 18 & 22 & 0 & 11 & 10 & 5 \\
Number of MPS liquid feed cows & 37 & 33 & 9 & 31 & 14 & 12 \\
Milk yield of PPS (kg/d) & 32.2 & 36.3 & - & 31.9 & 30.8 & 34.3 \\
Milk yield of MPS (kg/d) & 37.0 & 45.1 & 42.7 & 42.2 & 42.0 & 43.9 \\
Milking frequency of PPS (milkings/d) & 2.9 & 3.5 & - & 3.2 & 3.1 & 2.9 \\
Milking frequency of MPS (milkings/d) & 3.1 & 3.4 & 3.3 & 3.4 & 3.3 & 3.4 \\
\hline
\end{tabular}

${ }^{1}$ Average daily milk yield and milk frequency from 0 to 60 DIM.

${ }^{2}$ Parity = primiparous (PPS) or multiparous (MPS).

${ }^{3}$ Treatments consisted of (1) control = standard AMS pellet + no molasses-based liquid feed addition in the AMS or (2) liquid feed $=$ standard AMS pellet + molasses-based liquid feed $[1 \mathrm{~kg}$ of DM/d of liquid feed for MPS cows $(1.6 \mathrm{~kg} / \mathrm{d}$ as fed) and $0.88 \mathrm{~kg}$ of DM/d for PPS cows $(1.4 \mathrm{~kg} / \mathrm{d}$ as fed)]. Treatments were administered over 60 DIM beginning the day of calving.

${ }^{4}$ Farm 3 only milked MPS cows. 
fore calving (Table 2). Cows were moved into maternity pens around the time of calving. Following calving, at 4 farms, cows were moved into fresh cow pens with access to an AMS and then released into the lactating herd within 3 to 5 DIM. At 2 of the farms, fresh cows were moved directly to the main pen of lactating cows. All farms milked using a Lely Astronaut (Lely Industries N.V., Maassluis, the Netherlands). Milk settings, such as maximum milkings/d and optimal milk yields/milking, were recorded for each farm (Table 3). All farms had freestall housing, with free-flow cow traffic access to the AMS. All cows were given ad libitum access to water and lying stalls, as stocking density was never more than $100 \%$ (cows/stall) across all 6 farms. All AMS feed table settings were recorded for each farm; these settings varied by parity (Figure 1). Across farms, cows were fed a similar pelleted concentrate at the AMS (Table 4). Furthermore, all farms fed a similar partial mixed ration (PMR) at the feed bunk, formulated to meet the production needs of the cows at those respective farms (Table 5). All farms fed similar PMR components, consisting primarily of corn silage, alfalfa haylage, corn, soybeans, and vitamins and minerals. Across all farms, the PMR was formulated for an average DMI of $21.5 \pm 1.76$ (mean $\pm \mathrm{SD}$ ) $\mathrm{kg} / \mathrm{d}$.

\section{Experimental Design}

Sample size and power analyses were used to calculate (as per Morris, 1999) the minimum number of replicates needed per treatment $(n=180)$ to detect a $5 \%$ level of observed mean difference, with an average coefficient of variation of $24 \%$ for the primary continuous outcome variables, including rumination, milking activity, milk yield, and composition. We also calculated that this minimum number of replicates per treatment could achieve a predicted 5\% decrease in incidence of early-lactation disorders (SCK; Abramson, 2011).

Across study herds, we conducted a randomized controlled trial where 7 to $10 \mathrm{~d}$ before calving, cows were randomly assigned to 1 of 2 treatments within farm, ensuring that treatments were balanced according to parity [primiparous (PPS) and multiparous (MPS)]. The 2 treatments were applied at calving and consisted of (1) control group (CON) with standardized pelleted concentrate feeding through the AMS (MPS, $\mathrm{n}=133$; PPS, $\mathrm{n}=55$ ) or (2) liquid feed group (LF) with standardized pelleted concentrate feeding plus $1 \mathrm{~kg} / \mathrm{d}$ DM for MPS or $0.88 \mathrm{~kg} / \mathrm{d}$ DM for PPS of a molasses-based liquid feed blend (Table $6 ; 1.6 \mathrm{~kg} / \mathrm{d}$ as fed for MPS cows, $1.4 \mathrm{~kg} / \mathrm{d}$ as fed for PPS cows; MPS, $\mathrm{n}=136$; PPS, $\mathrm{n}=66$ ) supplemented directly into the AMS feed bowl at the same time AMS pellets were dispensed at each milking. The daily LF allotment for LF cows was split equally by the AMS across milkings/d, similar to daily AMS pellet delivery. The molasses-based liquid feed (Liquid Feeds International, Innerkip, Ontario, Canada) contained a mixture of sugarcane molasses, beet sugar molasses, condensed cultured whey, calcium chloride, QLF 120\% [Reg \# 982679, Quality Liquid Feeds (QLF), Dodgeville, WI; a slow-release urea product], and phosphoric acid. Across all farms enrolled in this study, from 0 to 7 DIM, AMS feed table settings, and subsequent actual amounts delivered, for LF were

Table 2. Nutrient composition ${ }^{1}$ (mean $\pm \mathrm{SD}$ ) of the dry cow TMR fed to all cows by farm (1-6)

\begin{tabular}{|c|c|c|c|c|c|c|}
\hline Item & \multicolumn{6}{|c|}{ Dry cow TMR } \\
\hline DM, \% & $44.9 \pm 2.75$ & $47.6 \pm 7.29$ & $56.6 \pm 5.18$ & $54.8 \pm 5.18$ & $58.8 \pm 10.95$ & $57.7 \pm 15.27$ \\
\hline $\mathrm{ADF}, \%$ OF DM & $36.4 \pm 0.05$ & $24.5 \pm 0.03$ & $33.9 \pm 0.69$ & $26.8 \pm 0.001$ & $35.9 \pm 0.02$ & $32.4 \pm 0.01$ \\
\hline NDF, $\%$ of DM & $52.7 \pm 0.07$ & $42.2 \pm 0.02$ & $48.8 \pm 0.46$ & $40.4 \pm 0.001$ & $55.6 \pm 0.02$ & $50.6 \pm 0.02$ \\
\hline TDN, \% of DM & $60.6 \pm 0.04$ & $69.8 \pm 0.02$ & $62.4 \pm 0.92$ & $68.0 \pm 0.001$ & $60.9 \pm 0.02$ & $63.6 \pm 0.01$ \\
\hline Sugar, $\%$ of DM & $2.4 \pm 0.87$ & $5.1 \pm 0.31$ & $2.7 \pm 0.42$ & $6.6 \pm 0.92$ & $4.5 \pm 2.78$ & $1.8 \pm 0.29$ \\
\hline Fat, \% of DM & $3.6 \pm 0.00$ & $3.1 \pm 0.01$ & $3.8 \pm 0.47$ & $3.3 \pm 0.002$ & $2.6 \pm 0.003$ & $2.8 \pm 0.01$ \\
\hline Ash, $\%$ of DM & $7.6 \pm 0.01$ & $8.3 \pm 0.001$ & $9.2 \pm 0.83$ & $7.6 \pm 0.001$ & $6.0 \pm 0.002$ & $5.0 \pm 0.001$ \\
\hline $\mathrm{Ca}, \%$ of $\mathrm{DM}$ & $0.74 \pm 0.001$ & $0.94 \pm 0.001$ & $0.97 \pm 0.07$ & $0.92 \pm 0.001$ & $0.53 \pm 0.001$ & $0.46 \pm 0.001$ \\
\hline $\mathrm{P}, \%$ of $\mathrm{DM}$ & $0.28 \pm 0.001$ & $0.44 \pm 0.001$ & $0.38 \pm 0.02$ & $0.42 \pm 0.001$ & $0.22 \pm 0.001$ & $0.28 \pm 0.001$ \\
\hline $\mathrm{K}, \%$ of $\mathrm{DM}$ & $1.9 \pm 0.001$ & $1.4 \pm 0.001$ & $1.8 \pm 0.01$ & $1.5 \pm 0.001$ & $1.1 \pm 0.001$ & $1.0 \pm 0.001$ \\
\hline $\mathrm{Na}, \%$ of $\mathrm{DM}$ & $0.06 \pm 0.001$ & $0.20 \pm 0.001$ & $0.12 \pm 0.02$ & $0.16 \pm 0.001$ & $0.09 \pm 0.001$ & $0.14 \pm 0.001$ \\
\hline
\end{tabular}

\footnotetext{
${ }^{1}$ Values were obtained from chemical analysis of TMR samples.

${ }^{2}$ Farm 4 was the only farm to feed a close-up dry cow diet; all other farms fed the same dry cow diet to close-up and far-off dry cows. The closeup dry cow diet is presented in the table above.

${ }^{3} \mathrm{NE}_{\mathrm{L}}$ is the estimated energy needed for lactation and was calculated based on NRC (2001) equations.
} 


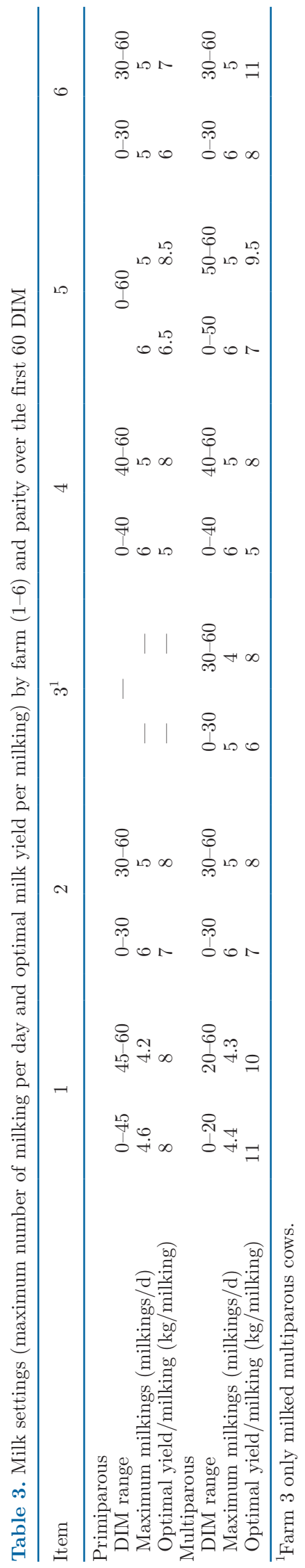

gradually increased for PPS cows from 0.7 to $1.4 \mathrm{~kg} / \mathrm{d}$, as fed (Figure 2a,b). Following d 7, all PPS cows received a flat rate of $1.4 \mathrm{~kg} / \mathrm{d}$ as fed. From 0 to 7 DIM, MPS cows were gradually increased in LF from 0.8 to $1.6 \mathrm{~kg} / \mathrm{d}$, as fed, and then remained at $1.6 \mathrm{~kg} / \mathrm{d}$ for the duration of the trial (Figure 2c,d). Cows received LF supplementation for the first $60 \mathrm{~d}$ postcalving. All cows within each farm received the same feeding plan of AMS pellets; however, pellet allotment was dependent on parity (Figure 1).

\section{Health Data Collection}

Blood samples were taken 2 times per week to assess BHB. Five BHB blood tests were taken in total, with test 1 occurring between 1 and 4 DIM, test 2 at 3 to 6 DIM, test 3 at 7 to 10 DIM, test 4 at 10 to 13 DIM, and test 5 occurring between 13 and 17 DIM.

Blood BHB was measured using an electronic handheld device (FreeStyle Precision Neo, Abbott Diabetes Care, Saint Laurent, QC, Canada), as validated by Kanz et al. (2015). Additionally, one blood sample was taken 7 to $10 \mathrm{~d}$ postcalving to determine serum nonesterified fatty acid (NEFA) concentration. Before calving, at the time of enrollment ( $\sim 10$ to $4 \mathrm{~d}$ before the expected calving date), one additional blood sample was taken for BHB and NEFA analysis and used as a covariate for the postcalving BHB and NEFA results. For blood sample collection, cows were restrained in a stall or headlocks to obtain blood from the coccygeal vein into a 10-mL red-top evacuated tube. Blood samples were placed upright in a cooler following collection and later centrifuged at $1,500 \times g$ at $18^{\circ} \mathrm{C}$ for 15 min to separate cells from serum. For each blood sample, $1.5 \mathrm{~mL}$ of serum was placed into a 3 - $\mathrm{mL}$ tube and frozen at $-20^{\circ} \mathrm{C}$ until the time of analysis. Serum samples were sent to the Animal Health Laboratory, University of Guelph (Guelph, ON, Canada), where they were then analyzed for NEFA (reagent supplied by Randox Laboratories, Crumlin, United Kingdom) using a photometric test on the Roche Cobas 6000 c501 instrument (Roche, Indianapolis, IN).

Cows were diagnosed as having SCK if blood BHB concentrations were $\geq 1.2 \mathrm{mmol} / \mathrm{L}$ (McArt et al., 2012). The incidence of repeat positive SCK tests was categorized by grouping cows into 3 categories based on the number of times each cow tested positive for SCK across the first 17 DIM. Cows were categorized as never having SCK if they never experienced any positive SCK results, low if they had 1 or 2 positive SCK tests, and high if they had $\geq 3$ SCK positive tests.

Body condition score was recorded for each cow starting the day of enrollment (7-10 d precalving), at the day of calving, and every $10 \mathrm{~d}$ thereafter. Scores 
Table 4. Nutrient composition ${ }^{1}$ (mean $\pm \mathrm{SD}$ ) of the automated milking system (AMS) pellets fed to all cows by farm (1-6) during milking

\begin{tabular}{|c|c|c|c|c|c|c|}
\hline Item & \multicolumn{6}{|c|}{ AMS pellet } \\
\hline DM, $\%$ & $91.2 \pm 2.04$ & $89.0 \pm 2.87$ & $88.5 \pm 2.87$ & $89.1 \pm 2.14$ & $90.1 \pm 3.72$ & $90.7 \pm 3.72$ \\
\hline Starch, \% of DM & $24.6 \pm 0.03$ & $37.0 \pm 0.01$ & $26.9 \pm 0.001$ & $37.5 \pm 0.02$ & $32.6 \pm 0.03$ & $25.2 \pm 0.001$ \\
\hline Sugar, $\%$ of DM & $12.1 \pm 2.67$ & $8.4 \pm 0.36$ & $13.0 \pm 0.56$ & $8.9 \pm 0.70$ & $11.6 \pm 0.38$ & $9.6 \pm 0.43$ \\
\hline $\mathrm{Ca}, \%$ of $\mathrm{DM}$ & $0.58 \pm 0.001$ & $1.3 \pm 0.001$ & $1.2 \pm 0.001$ & $0.49 \pm 0.001$ & $0.82 \pm 0.001$ & $0.96 \pm 0.001$ \\
\hline $\mathrm{Mg}, \%$ of $\mathrm{DM}$ & $0.61 \pm 0.001$ & $0.43 \pm 0.001$ & $0.33 \pm 0.001$ & $0.29 \pm 0.001$ & $0.48 \pm 0.001$ & $0.34 \pm 0.001$ \\
\hline
\end{tabular}

${ }^{1}$ Values were obtained from chemical analysis of AMS pellet samples.

were determined using a 5-point scale, as described by Wildman et al. (1982). Lameness was assessed by gait scoring each cow every $10 \mathrm{~d}$, starting the day of enroll- ment. Gait scores were determined by using a 5 -point ordinal scale (Flower and Weary, 2006). Two observers assessed BCS and lameness for the entire duration of
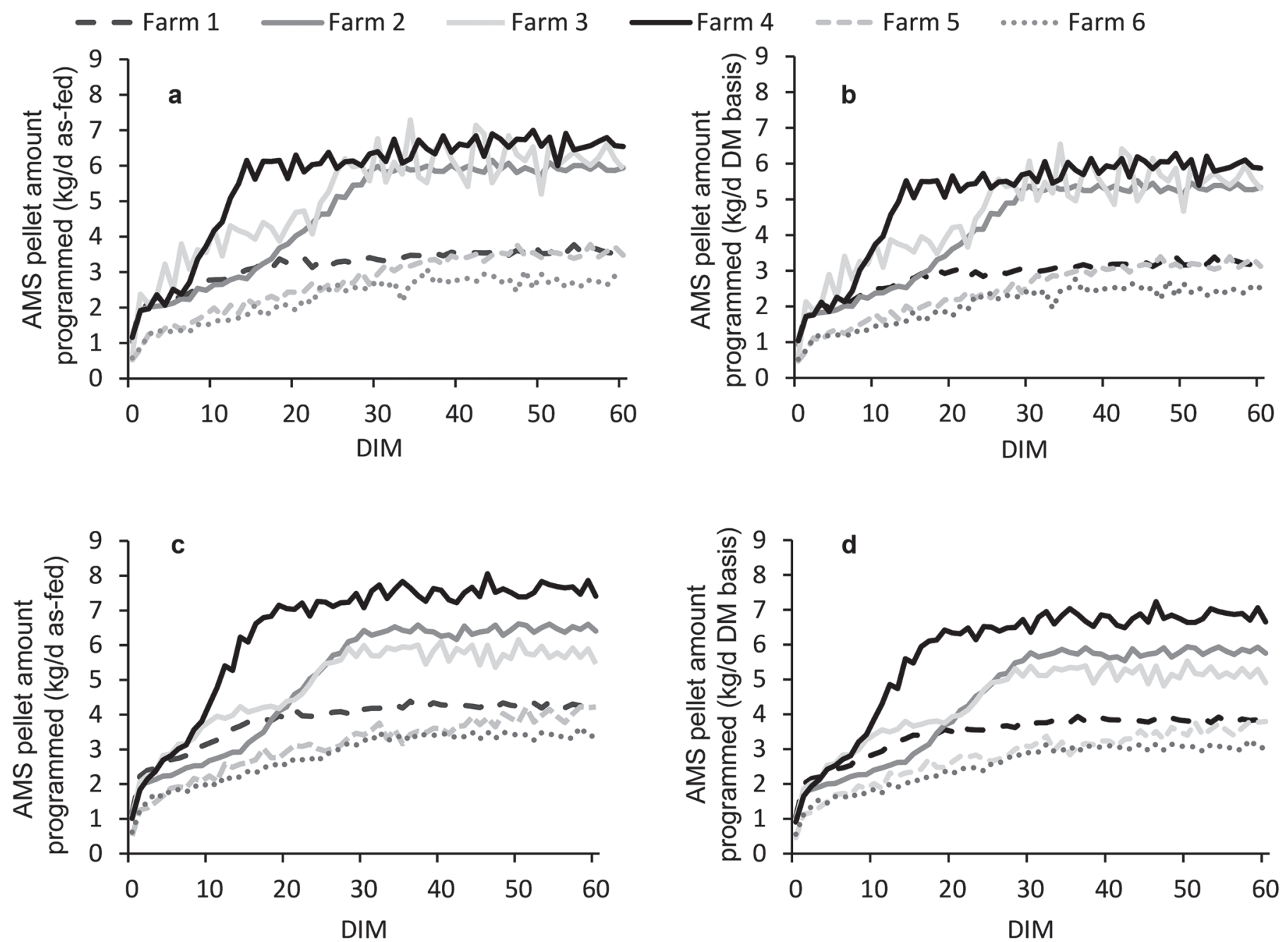

Figure 1. Automated milking system (AMS) pellet amount programmed (kg/d) by farm for (a) primiparous cows on an as-fed basis, (b) primiparous cows on a DM basis, (c) multiparous cows on an as-fed basis, and (d) multiparous cows on a DM basis. All cows were fed in AMS and feed tables were created within Lely T4C software (Lely Industries N.V., Maassluis, the Netherlands). 
Table 5. Nutrient composition ${ }^{1}$ (mean $\pm \mathrm{SD}$ ) of the lactating cow partial mixed ration (PMR) fed to all cows by farm (1-6)

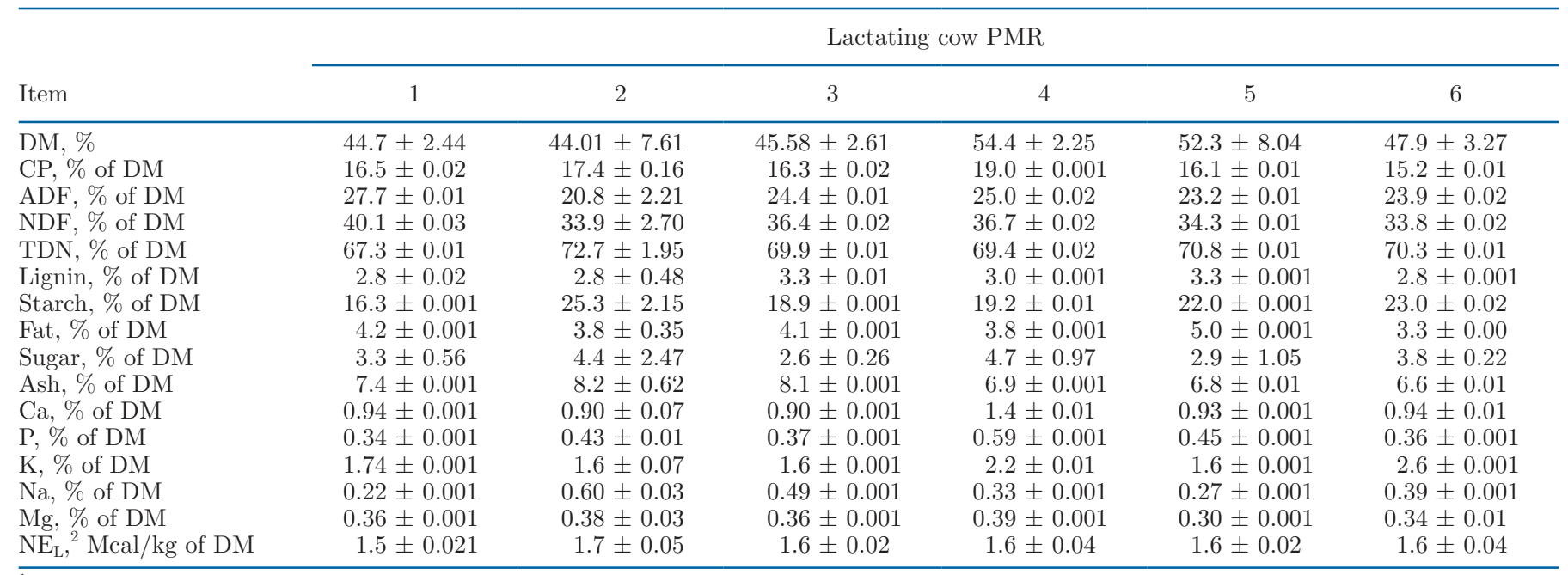

${ }^{1}$ Values were obtained from chemical analysis of PMR samples.

${ }^{2} \mathrm{NE}_{\mathrm{L}}$ is the estimated energy needed for lactation and was calculated based on NRC (2001) equations.

the trial and performed an interreliability test before the commencement of the trial, to ensure acceptable reliability (kappa $=0.85$ and 0.90 for $\mathrm{BCS}$ and gait scoring, respectively). The frequency of lameness diagnosis was summarized using the same methodology as the frequency of repeated SCK cases. Cows with a gait score of $\geq 3$ were classified as lame and grouped within 3 categories based on the number of times they were diagnosed as lame across the first 60 DIM. Cows were categorized as never lame if they never detected as lame, low if they were determined as lame 1 or 2 times, and high if they were detected as lame $\geq 3$ times.

Rumination time was monitored continuously using an electronic rumination monitoring system (Hi-Tag, SCR Engineers Ltd., Netanya, Israel), as validated by Schirmann et al. (2009). Rumination data loggers were attached to cow identification collars and followed cows continuously beginning a minimum of 14 $\mathrm{d}$ before calving, with the exception of farm 5, which fitted rumination collars $1 \mathrm{~d}$ before the expected calving date. Rumination time and activity were recorded $24 \mathrm{~h} / \mathrm{d}$ for the duration of the experiment (60 DIM), and continuously uploaded to a control unit through a radio frequency reader and transferred to $\mathrm{T} 4 \mathrm{C}$ software (Time-for-Cows, Lely Industries N.V.). These data, stored in 2-h intervals, were then used to determine the total time spent ruminating throughout each day for each cow.

\section{Milking Characteristics, Components, and Analyses}

Postcalving milk production, milking frequency, refusal frequency, and total AMS visit frequency were recorded daily by the Lely T4C software associated with the AMS units on each farm. Milk samples were taken once every 3 wk from each cow on each farm across 2 consecutive days, starting at 6 DIM using a milk sampling device (Lely Shuttle Sampling Device, Lely

Table 6. Nutrient composition ${ }^{1}$ (mean $\pm \mathrm{SD}$ ) of the molasses-based liquid feed fed to liquid feed treatment cows by farm (1-6)

\begin{tabular}{lrrrrr}
\hline & \multicolumn{5}{c}{ Molasses-based liquid feed } \\
\cline { 2 - 6 } Item & \multicolumn{1}{c}{1} & \multicolumn{1}{c}{3} & \multicolumn{1}{c}{4} & 5 \\
\hline DM, \% & $60.5 \pm 1.2$ & $60.9 \pm 0.42$ & $59.8 \pm 0.21$ & $60.9 \pm 0.07$ & $60.6 \pm 0.14$ \\
CP, \% of DM & $17.3 \pm 0.38$ & $17.0 \pm 0.95$ & $16.2 \pm 0.18$ & $16.5 \pm 0.40$ & $16.0 \pm 0.91$ \\
Sugar, \% of DM & $60.1 \pm 1.55$ & $59.8 \pm 0.65$ & $59.6 \pm 3.05$ & $60.8 \pm 3.65$ & $57.4 \pm 0.80$ \\
NPN, \% of DM & $9.3 \pm 0.88$ & $9.6 \pm 0.64$ & $9.0 \pm 0.76$ & $9.8 \pm 0.13$ & $9.4 \pm 0.48$ \\
Ca, \% of DM & $2.0 \pm 0.13$ & $2.1 \pm 0.20$ & $2.0 \pm 0.01$ & $2.2 \pm 0.07$ & $2.1 \pm 0.16$ \\
P, \% DM & $0.70 \pm 0.04$ & $0.62 \pm 0.04$ & $0.68 \pm 0.01$ & $0.62 \pm 0.04$ & $0.70 \pm 0.01$ \\
K, \% of DM & $7.9 \pm 0.49$ & $7.5 \pm 0.71$ & $7.6 \pm 0.54$ & $5.0 \pm 1.90$ & $3.6 \pm 0.25$ \\
\hline
\end{tabular}

${ }^{1}$ Values were obtained from the chemical analysis of liquid molasses samples.

${ }^{2}$ Total sugars as invert. 

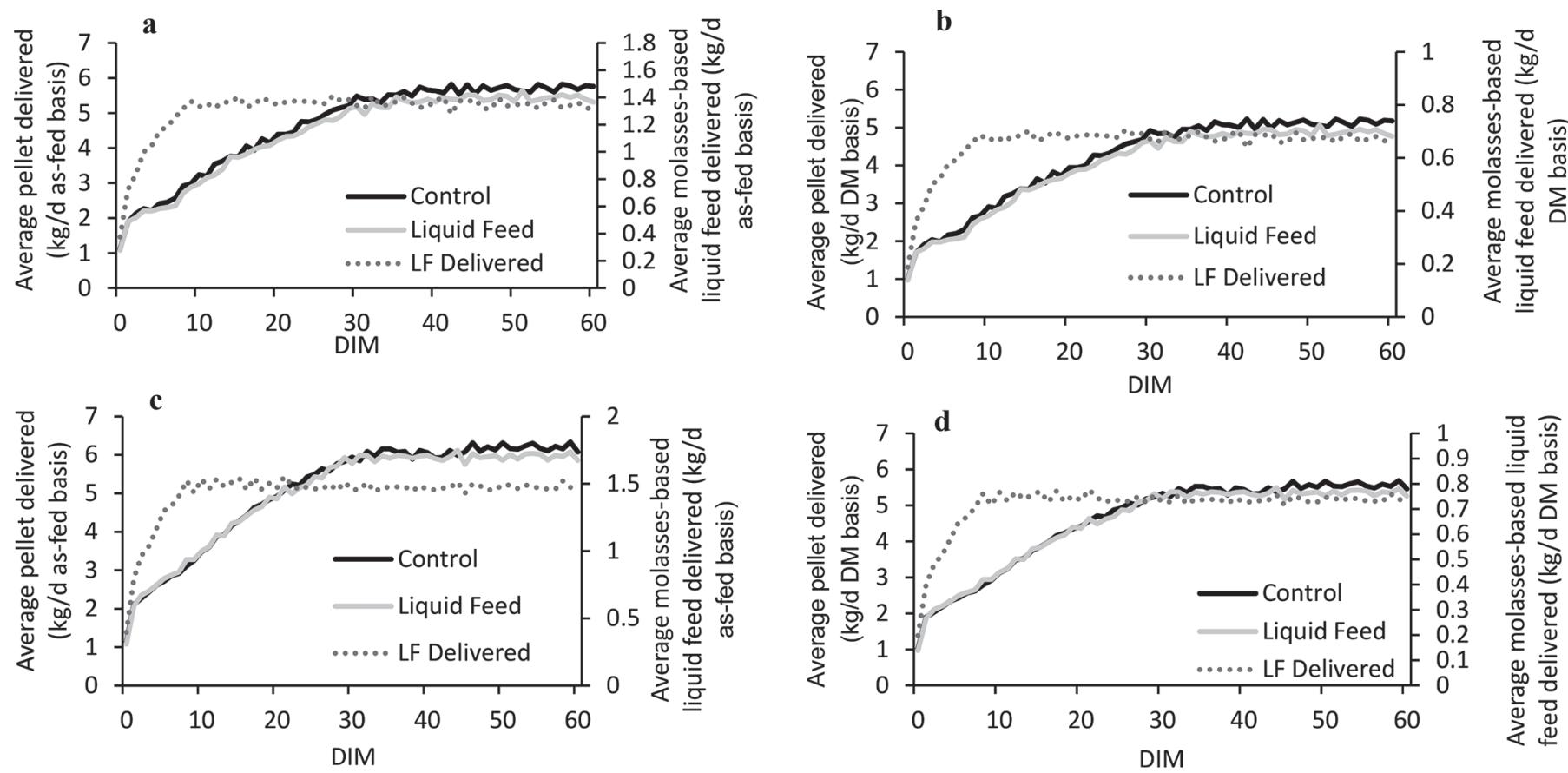

Figure 2. The average pellet and molasses-based liquid feed (LF) delivered to (a) primiparous cows on an as-fed basis, (b) primiparous cows on a DM basis, (c) multiparous cows on an as-fed basis, and (d) multiparous cows on a DM basis. Liquid feed cows received a standard automated milking system (AMS) pellet + molasses-based liquid feed $[1 \mathrm{~kg}$ of DM/d of LF for multiparous cows (1.6 kg/d as fed) and $0.88 \mathrm{~kg}$ of DM/d for primiparous cows $(1.4 \mathrm{~kg} / \mathrm{d}$ as fed)]. Treatments were administered over $60 \mathrm{DIM}$ beginning the day of calving.

Industries N.V.). These samples were sent to a DHI testing laboratory (CanWest DHI, Guelph, ON, Canada) and analyzed using a Fourier Transform Infrared full spectrum analyzer (Milkoscan FT+ and Milkoscan 6000; Foss, Hillerod, Denmark) for components (fat and protein), SCC, and MUN. Cow production and components were recorded until 60 DIM. These values were then summarized to generate an average milk fat, protein, SCC, and MUN value per cow per farm and per test week.

Milk composition samples were used to determine the yield of $4 \% \mathrm{FCM}(\mathrm{kg} / \mathrm{d})$, calculated as $[0.4 \times$ milk yield $(\mathrm{kg} / \mathrm{d})]+[15.0 \times$ fat yield $(\mathrm{kg} / \mathrm{d})](\mathrm{NRC}, 2001)$. Energy-corrected milk was calculated as ECM $(\mathrm{kg} / \mathrm{d})$ $=(0.327 \times \mathrm{kg}$ of milk $)+(12.95 \times \mathrm{kg}$ of fat $)+(7.2 \times$ $\mathrm{kg}$ of protein) (Tyrrell and Reid, 1965).

\section{Feed Samples and Analyses}

Feed samples (of PMR, AMS pellets, and molassesbased LF) were taken once every 3 wk at each farm. Calibration of the AMS feed scale was also completed approximately every $3 \mathrm{wk}$ at each farm to ensure accurate amounts of AMS pellets and the molasses-based liquid feed were being dispensed and recorded. Feed samples were immediately frozen at $-20^{\circ} \mathrm{C}$ following collection, for later analyses of DM, particle size distribution (Table 7 ), and nutrient composition (Tables 2, $4,5$, and 6$)$.

After a 24-h period of thawing, PMR samples collected for particle size analysis were processed using a 4-screen Penn State Particle Separator (Maulfair and Heinrichs, 2013), which separated the sample into 4

Table 7. Particle size distribution ${ }^{1}$ (mean $\pm \mathrm{SD}$ ) of lactating partial mixed rations (PMR) by farm (1-6)

\begin{tabular}{|c|c|c|c|c|c|c|}
\hline Item & \multicolumn{6}{|c|}{ Lactating cow PMR } \\
\hline Long, \% of DM & $18.3 \pm 7.02$ & $15.5 \pm 6.52$ & $24.5 \pm 6.93$ & $5.7 \pm 2.53$ & $14.0 \pm 8.32$ & $9.4 \pm 1.20$ \\
\hline Short, \% of DM & $10.2 \pm 0.88$ & $13.1 \pm 5.02$ & $11.1 \pm 1.45$ & $15.8 \pm 1.51$ & $11.5 \pm 0.39$ & $14.5 \pm 1.18$ \\
\hline Fine, \% of DM & $15.7 \pm 4.69$ & $29.6 \pm 8.24$ & $21.5 \pm 3.65$ & $35.8 \pm 5.42$ & $30.2 \pm 9.89$ & $27.0 \pm 3.30$ \\
\hline
\end{tabular}

${ }^{1}$ Particle size determined by using a Penn State Particle Separator (PSPS; Maulfair and Heinrichs, 2013) to process feed samples. The PSPS had a 19-mm screen (long), 8-mm screen (medium), 4-mm screen (short), and a pan (fine). 
fractions based on particle size: long $(>19 \mathrm{~mm})$, me$\operatorname{dium}(<19>8 \mathrm{~mm})$, short $(<8>4 \mathrm{~mm})$, and fine $(<4 \mathrm{~mm})$. Separated samples were then oven-dried at $55^{\circ} \mathrm{C}$ for $48 \mathrm{~h}$.

Feed samples collected for nutrient composition analysis included the AMS pellet samples (Table 4), PMR samples (Table 5), and LF samples (Table 6). Following oven drying at $55^{\circ} \mathrm{C}$ for $48 \mathrm{~h}$, samples of PMR and AMS pellets were ground to pass through a 1-mm screen (Model 4 Wiley Laboratory Mill, Thomas Scientific, Swedesboro, NJ). Ground samples, pooled by week, were then sent to A\&L Laboratory Services Inc. (London, ON, Canada) for analysis of ash $\left(550^{\circ} \mathrm{C}\right.$; AOAC International, 2000: method 942.05), ADF (AOAC International, 2000: method 973.18), NDF with heat-stable $\alpha$-amylase and sodium sulfite (AOAC International, 2000: method 2002.04), $\mathrm{CP}(\mathrm{N} \times 6.25$; AOAC International, 2000: method 990.03; Leco FP628 Nitrogen Analyzer, Leco, St. Joseph, MI), and starch (heat-stable amylase and amyloglucosidase; AOAC International, 2000: method 996.11). Liquid molasses samples were collected from each farm at the AMS once a month and frozen before being sent to SDK Laboratories Inc. (Hutchinson, KS) for analysis of DM (AOAC International, 2000: method 966.20), CP (AOAC International, 2000: method 976.06), NPN (AOAC International, 2000: method 941.01), calcium and potassium (AOAC International, 2000: method 968.08), phosphorus (AOAC International, 2000: method 965.17), and total sugars as invert (AOAC International, 2000: method 968.28).

\section{Calculations and Statistical Analyses}

All statistical analyses were conducted using SAS 9.4 software (2013, SAS Institute Inc., Cary, NC). Significance was declared at $P \leq 0.05$ and tendencies at $P$ $\leq 0.1$. If the $P$-value of an interaction term was $\leq 0.05$ it was retained in the model; otherwise, interaction terms were removed from the model. All means are presented as least squares means. Before analyses, data were assessed for normality using the UNIVARIATE procedure of SAS. All assumptions of normality were met for majority of the data, except for SCC, which was normalized using the natural logarithm. In situations where rumination collars malfunctioned, or cows were removed from the milking herd, only days with complete data were included in the analyses.

Data were analyzed using repeated measures general linear mixed-effect regression models using the mixed procedure of SAS. To test the effect of treatment on blood BHB, serum NEFA, BCS, AMS data (AMS visits, milking frequency, milk yield, and milking refusals), milk components and rumination time, data were summarized by cow, treatment, and by measurement frequency (DIM or test day). When analyzing blood BHB, serum NEFA, BCS, and milk components, test (test day) was treated as a repeated measure. When analyzing rumination time and AMS data (milking activity and yield), DIM was treated as a repeated measure. For all models, farm and cow within farm were considered random effects. The fixed effects in each model were DIM/test (depending on measurement frequency), parity, and treatment, as well as interactions of DIM/test $\times$ treatment and parity $\times$ treatment. No parity $\times$ treatment interactions were detected, and therefore, all data presented are integrated across both parity groups (MPS and PPS). When treatment $\times \mathrm{DIM} /$ test interactions were detected, the PDIFF option was added to the LSMEANS statement to analyze for differences between treatments within individual DIM/test. Heterogeneous autoregressive, first order autoregressive, compound symmetry, or heterogeneous compound symmetry were selected as covariance structures for various models on the basis of best fit according to Schwarz's Bayesian information criterion.

Loss in BCS was determined by subtracting the BCS at 60 DIM from the BCS taken within the first week of calving. The change in BCS was then used as a dependent variable in the MIXED procedure of SAS and used to test the difference between treatments. Fixed effects of the model were parity and treatment; farm and cow within farm were included as random effects.

To determine the effect of treatment on incidence of repeated lameness diagnoses and the incidence of repeated positive SCK tests, data were analyzed using the PROC FREQ procedure of SAS. This model was then used to determine the percentages of high, low, and never categories. Significance was determined using chi-squared (with $P<0.05$ ) to determine associations between incidence category and treatment.

\section{RESULTS AND DISCUSSION}

The aim of this study was to determine how the addition of a molasses-based liquid feed supplement in AMS would affect fresh cow metabolic health and production. All cows were successfully delivered a similar (Figure 2; $P=0.19$ ) amount of their allotted AMS pellets for the first 60 DIM, with CON cows receiving $4.3 \pm 1.2 \mathrm{~kg} / \mathrm{d}$ and $\mathrm{LF}$ cows receiving $4.0 \pm 1.01 \mathrm{~kg} / \mathrm{d}$, on an as-fed basis (CON $=3.9 \mathrm{~kg} / \mathrm{d}$ on DM basis, LF $=3.6 \mathrm{~kg} / \mathrm{d}$ on DM basis). Multiparous cows on the LF treatment received, on average, $1.44 \mathrm{~kg} / \mathrm{d}$ of $\mathrm{LF}$ on an as-fed basis $(0.87 \mathrm{~kg} / \mathrm{d}$ on DM basis), and primiparous cows received, on average, $1.32 \mathrm{~kg} / \mathrm{d}$ of LF on an as-fed basis $(0.79 \mathrm{~kg} / \mathrm{d}$ on DM basis; Figure 2). 
To our knowledge, this is the first study to supplement a molasses-based liquid feed through AMS in attempt to improve metabolic health of cows in early lactation. However, no differences were detected in serum NEFA concentrations between treatments $(\mathrm{CON}$ $=0.73 \mathrm{mmol} / \mathrm{L}, \mathrm{LF}=0.77 \mathrm{mmol} / \mathrm{L} ; \mathrm{SE}=0.02, P=$ $0.48)$. The LF cows may not have been on the treatment long enough at the time of NEFA sampling (3 to $7 \mathrm{~d})$ to detect any effects. An interaction $(P=0.007)$ was present, however, between blood BHB test number and treatment (Figure 3), as BHB concentrations were lesser for LF cows at $\sim 15$ DIM compared with CON cows. This indicates that LF cows were not facing the same degree of NEB as CON cows at that time. Throughout the duration of the study, 193 cows (49.4\%) tested positive for SCK at $>1$ test (95 CON cows, 98 LF cows, $P=0.34$ ). The high incidence of SCK across both treatments may have been responsible for the lack of difference observed between LF and CON cows. Furthermore, the lack of a treatment effect on the overall incidence of SCK was supported by Ballard et al. (2001) who fed a supplement containing greater energy (containing $22 \%$ molasses, $45 \%$ beet pulp, $17 \%$ propylene glycol, and $16 \%$ calcium propionate) for $21 \mathrm{~d}$ precalving and $21 \mathrm{~d}$ postcalving and reported no difference in the incidence of SCK between control and supplemented cows. However, in the present study, treatment was associated with the number of times cows tested positive for SCK $(P=0.05)$; cows on LF had fewer repeat diagnoses of SCK, such that $15 \%$ of LF cows had $\geq 3$ positive SCK tests out of 5 tests, compared with $27 \%$ of CON cows (Figure 4). Therefore, CON cows not receiving additional molasses supplement at the AMS were $1.5 \times$ more likely to be diagnosed with $\mathrm{SCK} \geq 3 \times$ during early lactation compared with LF cows. Thus, it is likely that the daily additional energy supplementation helped support the metabolic demands of the cows over time, even though it did not elicit an immediate response. This is consistent with previous research that was focused on the effects of supplementing glycol to cows as a means to reduce NEB, because supplementation of smaller daily amounts across a longer period of time (mixed in a TMR, for example) can have less of an effect than orally drenching the cow across a shorter period of time (Duffield, 2000; Lien et al., 2010). Therefore, it is possible that a more immediate response with regard to metabolic health and overall SCK incidence may have been observed if LF was supplemented in higher dosages at the AMS during the first few weeks of lactation.

Supporting the BHB results was a tendency for LF cows to lose less body condition $(\mathrm{CON}=-0.36 \mathrm{BCS}$ units, $\mathrm{LF}=-0.25$ BCS units; $\mathrm{SE}=0.06 ; P=0.09$ ) and, thus, remain at a more constant BCS than $\mathrm{CON}$

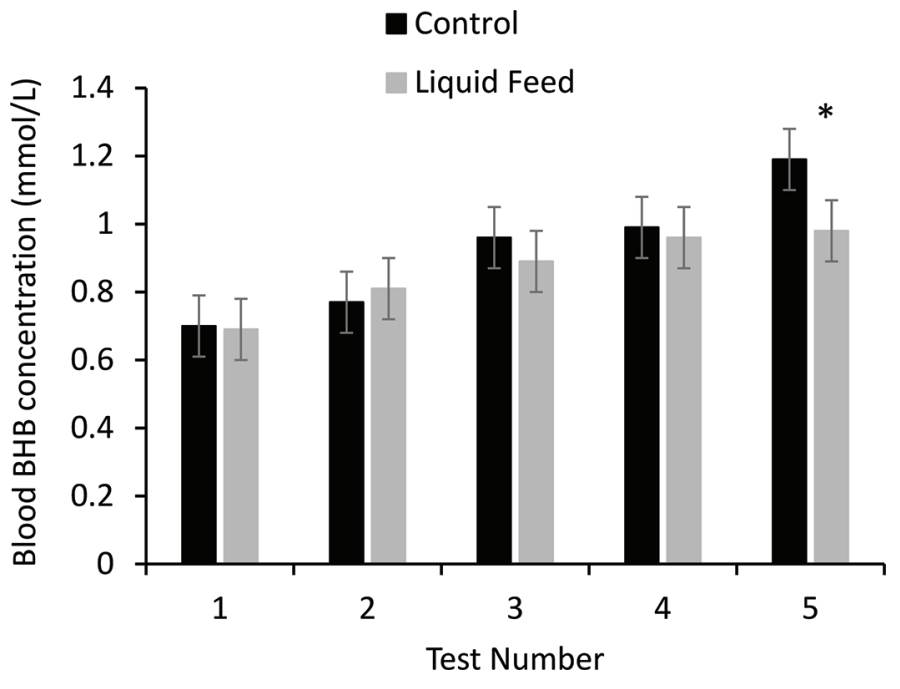

Figure 3. Effect of molasses-based liquid feed addition on blood BHB concentration $(\mathrm{mmol} / \mathrm{L})$ by test of early-lactation dairy cows milked in automated milking systems (AMS). Five BHB blood tests were taken: (1) test 1 occurring between 1 and 4 DIM, (2) test 2 at 3 to 6 DIM, (3) test 3 at 7 to 10 DIM, (4) test 4 at 10 to 13 DIM, and (5) test 5 occurring between 13 and 17 DIM. All cows had free-flow access to the AMS with control cows receiving only a standard AMS pellet; liquid feed cows received a standard AMS pellet + molasses-based liquid feed $[1 \mathrm{~kg}$ of DM/d of liquid feed for multiparous cows $(1.6 \mathrm{~kg} / \mathrm{d}$ as fed) and $0.88 \mathrm{~kg}$ of $\mathrm{DM} / \mathrm{d}$ for primiparous cows $(1.4 \mathrm{~kg} / \mathrm{d}$ as fed $)]$. Treatments were administered over 60 DIM beginning the day of calving. *indicates a significant difference between control and liquid feed cows where $P<0.05$.

cows throughout their first 60 DIM; CON cows lost $1.2 \times$ more body condition than LF cows in that time period. While the lower BHB concentrations at $\sim 15$ DIM, fewer repeat diagnoses of SCK, and lesser body condition loss reflect better energy balance for LF

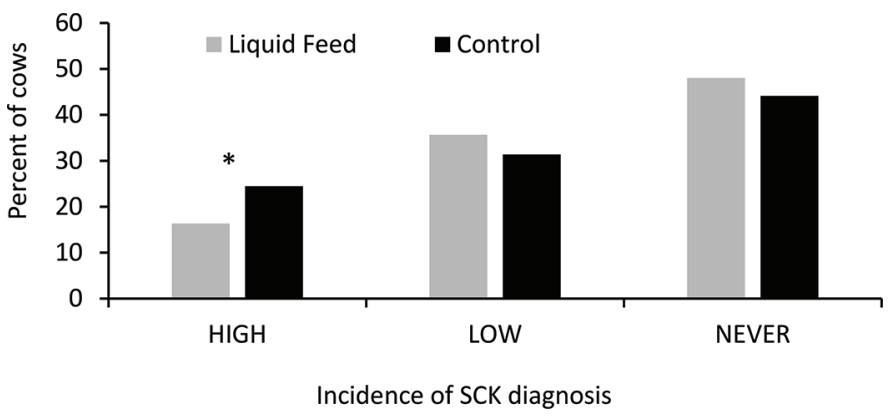

Figure 4. Percent of control and liquid feed cows experiencing repeated diagnoses of subclinical ketosis (SCK). All cows had freeflow access to the automated milking systems (AMS) with control cows receiving only a standard AMS pellet; liquid feed cows received a standard AMS pellet + molasses-based liquid feed $[1 \mathrm{~kg}$ of DM/d of liquid feed for multiparous cows $(1.6 \mathrm{~kg} / \mathrm{d}$ as fed $)$ and $0.88 \mathrm{~kg}$ of DM/d for primiparous cows $(1.4 \mathrm{~kg} / \mathrm{d}$ as fed)]. Treatments were administered over 60 DIM beginning the day of calving. *indicates a significant difference between control and liquid feed cows where $P<0.05$. High $\geq 3$ positive SCK tests; low $\leq 2$ positive tests. 
cows, no differences were detected between treatments for milk yield, ECM, and FCM (Table 8). Therefore, the extra energy from the LF was likely going toward maintaining milk production and reducing mobilization of body condition (fat) in the LF cows. These results are partially supported by Litherland et al. (2013) who reported that cows fed LF $42 \mathrm{~d}$ precalving to $56 \mathrm{~d}$ postcalving had greater BCS postpartum compared with cows fed a high-starch (grain) diet; however, they detected no differences between treatments with respect to the overall change in body condition across the first 56 DIM. Although researchers have previously investigated optimal sugar concentrations to be included in lactating cow diets to improve production (Broderick and Radloff, 2004), future research is still needed to understand how to effectively supplement sugars to early-lactation dairy cows to benefit both the production and metabolic health of the animal.

No differences were detected between treatments with regard to the incidence of lameness diagnosis $(P$ $=0.55) ; 44 \%$ of CON cows and $56 \%$ of LF cows were lame at some point during the study. As it has been reported that cows with greater losses in BCS from calving to 4 wk postcalving have an increased risk of lameness (Randall et al., 2015), it could be predicted that any differences in lameness incidence may occur as a result of differences in body condition loss. However, it is likely that the tendency for greater loss in BCS by the CON cows in the present study was not large enough to elicit any difference in lameness incidence. Green et al. (2014) reported that cows with lower BCS (typically a BCS $\leq 2.5$ ) are at a greater risk of lameness 2 to 4 mo following such a score. However, across all 390 cows enrolled in this study, only 12 cows between all 4 gait scores taken every $10 \mathrm{~d}$ within the first 60 DIM had a BCS $\leq 2.5$ ( $8 \mathrm{CON}$ cows and $4 \mathrm{LF})$. It is possible that a higher incidence of lameness may have been detected between 60 to 120 DIM, as cows typically continue to lose BCS up to and surrounding peak of lactation (Green et al., 2014).

Sugar supplementation has been demonstrated to encourage DMI (Penner and Oba, 2009) and promote rumen health (Oba, 2011), both related to greater rumination activity; thus, we hypothesized that supplementation of molasses would increase time spent ruminating. However, no difference in rumination time was detected between treatments (Table 8). In the absence of being able to monitor individual cow DMI of PMR, we can only speculate as to the reason why no difference was detected. A possible explanation is that the greater DMI from the LF at the AMS may have caused cows to displace some of their PMR consumption at the feed bunk. For example, Henriksen et al. (2019) reported a substitution effect for early-lactation dairy cows whereby, when more feed was supplemented at the AMS, less PMR was consumed at the bunk. Thus, it is possible that any gains in rumination time associated with the addition of LF were matched with reductions associated with lesser PMR consumption.

No differences between treatments were detected for total AMS visits (Figure 5; Table 8) or milking frequency (Table 8), as cows across both treatment groups

Table 8. Effect of molasses-based liquid feed addition on the milking activity, yield, and composition, and rumination time of early-lactation dairy cows milked in automated milking systems (AMS)

\begin{tabular}{|c|c|c|c|c|}
\hline \multirow[b]{2}{*}{ Item } & \multicolumn{2}{|c|}{ Treatment $^{1}$} & \multirow[b]{2}{*}{$\mathrm{SE}$} & \multirow[b]{2}{*}{$P$-value } \\
\hline & $\mathrm{CON}$ & $\mathrm{LF}$ & & \\
\hline \multicolumn{5}{|c|}{ Milking activity, yield, and components } \\
\hline AMS visits, no./d & 5.5 & 5.1 & 0.30 & 0.14 \\
\hline Milking frequency, no./d & 3.2 & 3.2 & 0.073 & 0.58 \\
\hline AMS refusals, no./d & 2.1 & 1.6 & 0.27 & 0.01 \\
\hline Milk yield, $\mathrm{kg} / \mathrm{d}$ & 37.5 & 37.2 & 1.98 & 0.67 \\
\hline $\mathrm{ECM}, \mathrm{kg} / \mathrm{d}$ & 39.0 & 39.1 & 1.39 & 0.87 \\
\hline $4 \% \mathrm{FCM}, \mathrm{kg} / \mathrm{d}$ & 36.3 & 36.3 & 1.33 & 0.96 \\
\hline Fat, \% & 3.9 & 3.9 & 0.10 & 0.89 \\
\hline Protein, \% & 3.1 & 3.1 & 0.04 & 0.39 \\
\hline Natural log-transformed $\mathrm{SCC}^{2}$ & 4.2 & 4.2 & 0.10 & 0.45 \\
\hline $\mathrm{SCC}^{3} \times 1,000$ cells $/ \mathrm{mL}$ & 64.7 & 68.5 & - & - \\
\hline $\mathrm{MUN}, \mathrm{mg} / \mathrm{dL}$ & 11.6 & 11.6 & 0.47 & 0.88 \\
\hline Rumination time, $\mathrm{min} / \mathrm{d}$ & 474.8 & 476.9 & 10.8 & 0.67 \\
\hline \multicolumn{5}{|c|}{$\begin{array}{l}{ }^{1} \text { Control }(\mathrm{CON})=\text { standard AMS pellet }+ \text { no molasses-based liquid feed addition in the AMS; liquid feed (LF } \\
=\text { standard AMS pellet }+ \text { molasses-based liquid feed }[1 \mathrm{~kg} \text { of } \mathrm{DM} / \mathrm{d} \text { of } \mathrm{LF} \text { for multiparous cows }(1.6 \mathrm{~kg} / \mathrm{d} \text { a } \\
\text { fed) and } 0.88 \mathrm{~kg} \text { of } \mathrm{DM} / \mathrm{d} \text { for primiparous cows }(1.4 \mathrm{~kg} / \mathrm{d} \text { as fed })] \text {. Treatments were administered over } 60 \mathrm{DIN} \\
\text { beginning the day of calving. } \\
\left.{ }^{2} \text { Somatic cell counts (cells } / \mathrm{mL}\right) \text { were natural log-transformed, given that they did not meet the assumption o } \\
\text { normality. }\end{array}$} \\
\hline
\end{tabular}


visited the AMS $\sim 5$ times/d, and successfully milked, on average, 3.2 times/d during the study. These results are surprising, as it was originally hypothesized that milking frequency would increase for LF cows due to the additional DM provided at the AMS and the high palatability of the molasses-based LF. Researchers have previously demonstrated that supplementing highly palatable feeds can encourage cows to visit the AMS (Morita et al., 1996; Madsen et al., 2010). Lessire et al. (2017) reported greater AMS visits and milking frequency for cows fed greater amounts of concentrates in the AMS and Madsen et al. (2010) reported greater milking frequencies depending on the composition of concentrates offered (wheat- and oat-based concentrates had higher milking frequencies than maize- or barleybased concentrates). However, Bach et al. (2007) reported no difference between the amount of concentrate offered at the AMS and the frequency of milking. We similarly observed no effect of LF provision on milking activity at the AMS. The lack of treatment effect on milking frequency in the present study may be related to the already high overall baseline average milking frequency (3.2 times/d). This milking frequency is high in comparison to that commonly observed in commercial settings; for example, Tremblay et al. (2016) reported an average milking frequency of 2.9 times/d across 635 North American AMS dairy herds. Thus, other housing and management factors might have a greater influence on overall milking frequency in the herds in the current study, thus limiting any potential effect of the dietary treatments. Additional research is needed to understand how an additional energy supplement, such as a molasses-based LF, may affect milking frequencies and AMS visits.

Interestingly, MPS cows not only produced more milk each day $(41.3$ vs. $32.3 \mathrm{~kg} / \mathrm{d} ; \mathrm{SE}=1.07 ; P=$ $0.001)$, but also milked more frequently each day (3.3 vs. 3.1 times $/ \mathrm{d} ; \mathrm{SE}=0.10 ; P=0.004)$ compared with PPS cows. Greater milk yield is expected for MPS cows compared with PPS cows in AMS (Deming et al., 2013; Vijayakumar et al., 2017). However, the milking frequency results of this study contradict previous studies were it has been reported that PPS milk more frequently per day in AMS than MPS cows (Borderas et al., 2008; King et al., 2017). The greater milking frequency for MPS cows observed in the current study could be related to the greater amount of total feed MPS cows received at the AMS as compared with PPS cows (Figure 2).

Differences were detected with regard to the number of AMS refusals per day; CON cows were refused by the AMS more often per day than cows receiving the LF supplement (Table 8; Figure 6). Although no other study, to our knowledge, has supplemented liquid molasses through AMS to early-lactation dairy cows, other researchers have manipulated the quantity and quality of concentrate offered at the AMS. Researchers have previously demonstrated that providing more concentrate at the AMS is associated with a greater number of AMS refusals, due to the high motivation of cows to access these palatable feeds (Tremblay et al., 2016; Lessire et al., 2017). It is possible that the LF cows in the current study, due to the extra energy supplement they were receiving, were more satiated throughout the day and, thus, were not as motivated to go to the AMS as often to seek out feed. However, without PMR consumption data, we cannot verify why CON cows were refused more often from the AMS than LF cows. Future research is needed to investigate the associations of extra energy supplementation of earlylactation cows at the AMS with DMI at the feed bunk, milking characteristics (visits, frequency, refusals), and AMS efficiency (free time vs. time in use for milking vs. refusals).

No differences were detected between treatments in milk fat content, milk CP content, or the concentrations of MUN and SCC (Table 8). This was consistent with Litherland et al. (2013) who reported no treatment differences for milk fat (\%), milk protein (\%), MUN (mg/dL), or SCC (cells/mL) for cows fed supplemental sugar (as opposed to starch). Additionally, DeVries and Gill (2012) also observed no differences in milk fat or protein content for cows supplemented with a molassesbased liquid feed.

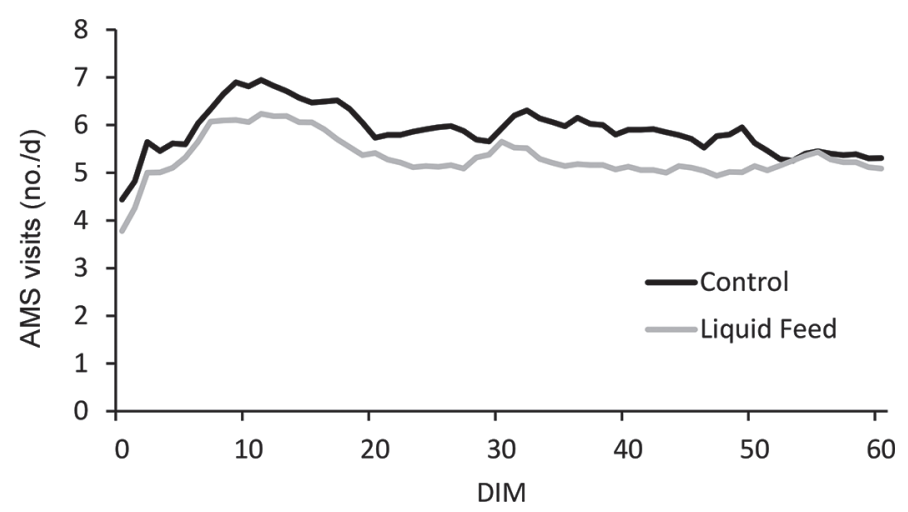

Figure 5. Number of times per day control and liquid feed cows visited the automated milking systems (AMS) across their first 60 DIM. All cows had free-flow access to the AMS with control cows receiving only a standard AMS pellet; liquid feed cows received a standard AMS pellet + molasses-based liquid feed $[1 \mathrm{~kg}$ of DM/d of liquid feed for multiparous cows $(1.6 \mathrm{~kg} / \mathrm{d}$ as fed) and $0.88 \mathrm{~kg}$ of $\mathrm{DM} / \mathrm{d}$ for primiparous cows $(1.4 \mathrm{~kg} / \mathrm{d}$ as fed)]. Treatments were administered over 60 DIM beginning the day of calving. 


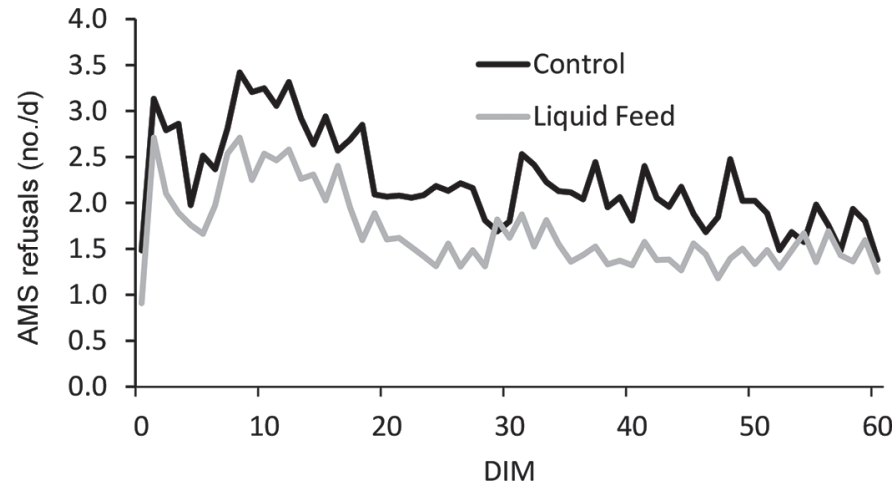

Figure 6. Number of times per day control and liquid feed cows were refused from the automated milking systems (AMS) throughout their first 60 DIM. All cows had free-flow access to the AMS with control cows receiving only a standard AMS pellet; liquid feed cows received a standard AMS pellet + molasses-based liquid feed $[1 \mathrm{~kg}$ of $\mathrm{DM} / \mathrm{d}$ of liquid feed for multiparous cows $(1.6 \mathrm{~kg} / \mathrm{d}$ as fed) and 0.88 $\mathrm{kg}$ of $\mathrm{DM} / \mathrm{d}$ for primiparous cows $(1.4 \mathrm{~kg} / \mathrm{d}$ as fed)]. Treatments were administered over 60 DIM beginning the day of calving.

\section{CONCLUSIONS}

Supplementing a molasses-based liquid feed to earlylactation dairy cows milked in AMS demonstrated positive benefits for cow metabolic health, but did not affect production outcomes or rumination behavior as hypothesized. Cows receiving this extra energy supplementation across the first 60 DIM displayed lower blood BHB levels by 15 DIM and had fewer repeat positive tests for SCK. Additionally, LF cows lost less body condition over the first 60 DIM compared with CON cows. Therefore, supplementing a molasses-based liquid feed to fresh cows milked in AMS may be an effective way to supply additional energy to cows during a period of NEB.

\section{ACKNOWLEDGMENTS}

The authors thank all the farmers who welcomed us onto their farms to collect samples and data for this project. Special thanks to Felipe Padua, Tiphaine Didry, Kaitlyn Dancy, Casey Havekes, and Anne Hoogeveen of the University of Guelph (Guelph, ON, Canada) for their assistance with data collection. This project was financially supported by a Natural Sciences and Engineering Research Council of Canada (NSERC; Ottawa, ON, Canada) Collaborative Research and Development Grant with Liquid Feeds International (Innerkip, Ontario, Canada) and from Quality Liquid Feeds (Dodgeville, WI). Further, equipment for this project was supported through contributions from the Canadian Foundation for Innovation (CFI; Ottawa, ON, Canada) and the Ontario Research Fund (Toronto,
ON, Canada). The authors have not stated any conflicts of interest.

\section{REFERENCES}

Abramson, J. H. 2011. WINPEPI updated: Computer programs for epidemiologists, and their teaching potential. Epidemiol. Perspect. Innov. 8:1. https://doi.org/10.1186/1742-5573-8-1.

AOAC International. 2000. Official Methods of Analysis. Vol. I. 17th ed. AOAC International, Arlington, VA.

Bach, A., and V. Cabrera. 2017. Robotic milking: Feeding strategies and economic returns. J. Dairy Sci. 100:7720-7728. https://doi .org/10.3168/jds.2016-11694.

Bach, A., C. Iglesias, S. Calsamiglia, and M. Devant. 2007. Effect of amount of concentrate offered in automatic milking systems on milking frequency, feeding behavior, and milk production of dairy cattle consuming high amounts of corn silage. J. Dairy Sci. 90:5049-5055. https://doi.org/10.3168/jds.2007-0347.

Ballard, C. S., P. Mandebvu, C. J. Sniffen, S. M. Emanuele, and M. P. Carter. 2001. Effect of feeding an energy supplement to dairy cows pre- and postpartum on intake, milk yield, and incidence of ketosis. Anim. Feed Sci. Technol. 93:55-69. https://doi.org/10 .1016/S0377-8401(01)00270-X.

Borderas, T. F., A. Fournier, J. Rushen, and A. M. B. de Passille. 2008. Effect of lameness on dairy cows' visits to automatic milking systems. Can. J. Anim. Sci. 88:1-8. https://doi.org/10.4141/ CJAS07014.

Broderick, G. A., and W. J. Radloff. 2004. Effect of molasses supplementation on the production of lactating dairy cows fed diets based on alfalfa and corn silage. J. Dairy Sci. 87:2997-3009. https: //doi.org/10.3168/jds.S0022-0302(04)73431-1.

Canadian Council on Animal Care. 2009. Guidelines On: The Care and Use of Farm Animals in Research, Teaching and Testing. Canadian Council on Animal Care, Ottawa, ON, Canada.

de Koning, C. 2011. Automatic milking: Common practice on over 10,000 dairy farms worldwide. Proceedings of the Dairy Research Symposium, 6-7 July 2011, Camden, Australia, University of Sydney.

Deming, J. A., R. Bergeron, K. E. Leslie, and T. J. DeVries. 2013. Associations of cow-level factors, frequency of feed delivery, and standing and lying behaviour of dairy cows milked in an automatic system. Can. J. Anim. Sci. 93:427-433. https://doi.org/10.4141/ cjas2013-055.

de Ondarza, M. B., S. M. Emanuele, and C. J. Sniffen. 2017. Effect of increased dietary sugar on dairy cow performance as influenced by diet nutrient components and level of milk production. Prof. Anim. Sci. 33:700-707. https://doi.org/10.15232/pas.2017-01648.

DeVries, T. J., and R. M. Gill. 2012. Adding liquid feed to a total mixed ration reduces feed sorting behavior and improves productivity of lactating dairy cows. J. Dairy Sci. 95:2648-2655. https:// doi.org/10.3168/jds.2011-4965.

Duffield, T. F. 2000. Subclinical ketosis in lactating dairy cattle. Vet. Clin. North Am. Food Anim. Pract. 16:231-253. https://doi.org/ 10.1016/S0749-0720(15)30103-1.

Flower, F. C., and D. M. Weary. 2006. Effect of hoof pathologies on subjective assessments of dairy cow gait. J. Dairy Sci. 89:139-146. https://doi.org/10.3168/jds.S0022-0302(06)72077-X.

Green, L. E., J. N. Huxley, C. Banks, and M. J. Green. 2014. Temporal associations between low body condition, lameness and milk yield in a UK dairy herd. Prev. Vet. Med. 113:63-71. https://doi.org/10 .1016/j.prevetmed.2013.10.009.

Henriksen, J. C. S., M. R. Weisbjerg, P. Løvendahl, T. Kristensen, and L. Munksgaard. 2019. Effects of an individual cow concentrate strategy on production and behavior. J. Dairy Sci. 102:2155-2172. https://doi.org/10.3168/jds.2018-15477.

Kanz, P., M. Drillich, D. Klein-Jöbstl, B. Mair, S. Borchardt, L. Meyer, I. Schwendenwein, and M. Iwersen. 2015. Suitability of capillary blood obtained by a minimally invasive lancet technique to detect subclinical ketosis in dairy cows by using 3 different elec- 
tronic hand-held devices. J. Dairy Sci. 98:6108-6118. https://doi .org/10.3168/jds.2014-8957.

King, M. T. M., S. J. LeBlanc, E. A. Pajor, and T. J. DeVries. 2017. Cow-level associations of lameness, behavior, and milk yield of cows milked in automated systems. J. Dairy Sci. 100:4818-4828. https://doi.org/10.3168/jds.2016-12281.

King, M. T. M., K. J. Sparkman, S. J. LeBlanc, and T. J. DeVries. 2018. Milk yield relative to supplement intake and rumination time differs by health status for fresh cows milked with automated systems. J. Dairy Sci. 101:10168-10176. https://doi.org/10.3168/ jds.2018-14671.

Lessire, F., E. Froidmont, J. Shortall, J. L. Hornick, and I. Dufrasne. 2017. The effect of concentrate allocation traffic and milk production of pasture-based cows milked by an automatic milking system. Animal 11:2061-2069.

Lien, T. F., L. B. Chang, Y. M. Horng, and C. P. Wu. 2010. Effects of propylene glycol on milk production, serum metabolites and reproductive performance during the transition period of dairy cows. J. Anim. Sci. 23:372-378. https://doi.org/10.5713/ajas.2010.60620.

Litherland, N. B., D. N. L. da Silva, W. P. Hansen, L. Davis, S. Emanuele, and H. Blalock. 2013. Effects of prepartum controlled-energy wheat straw and grass hay diets supplemented with starch or sugar on periparturient dairy cow performance and lipid metabolism. J. Dairy Sci. 96:3050-3063. https://doi.org/10.3168/jds.2012-5998.

Madsen, J., M. R. Weisbjerg, and T. Hvelplund. 2010. Concentrate composition for automatic milking systems - Effect on milking frequency. Livest. Sci. 127:45-50. https://doi.org/10.1016/j.livsci 2009.08.005

Maulfair, D. D., and A. J. Heinrichs. 2013. Effects of varying forage particle size and fermentable carbohydrates on feed sorting, ruminal fermentation, and milk and component yields of dairy cows. J. Dairy Sci. 96:3085-3097. https://doi.org/10.3168/jds.2012-6048.

McArt, J. A., A. D. V. Nydam, and G. R. Oetzel. 2012. Epidemiology of subclinical ketosis in early lactation dairy cattle. J. Dairy Sci. 95:5056-5066. https://doi.org/10.3168/jds.2012-5443.

McCarthy, M. M., T. Yasui, C. M. Ryan, S. H. Pelton, G. D. Mechor, and T. R. Overton. 2015. Metabolism of early-lactation dairy cows as affected by dietary starch and monensin supplementation. J. Dairy Sci. 98:3351-3365. https://doi.org/10.3168/jds.2014-8821.

Morita, S., S. Devir, C. Ketelaar-de Lauwere, A. C. Smits, H. Hogeveen, and J. H. M. Metz. 1996. Effects of concentrate intake on subsequent roughage intake and eating behavior of cows in an automatic milking system. J. Dairy Sci. 79:1572-1580. https://doi .org/10.3168/jds.S0022-0302(96)76519-0.

Morris, T. R. 1999. Experimental Design and Analysis in Animal Sciences. CABI Publishing, New York, NY.

NRC. 2001. Nutrient Requirements for Dairy Cattle. Natl. Acad. Sci., Washington, DC.

Oba, M. 2011. Review: Effects of feeding sugars on productivity of lactating dairy cows. Can. J. Anim. Sci. 91:37-46. https://doi.org/ 10.4141/CJAS10069.
Penner, G. B., and M. Oba. 2009. Increasing dietary sugar concentration may improve dry matter intake, ruminal fermentation and of productivity of dairy cows in the post-partum phase of the transition period. J. Dairy Sci. 92:3341-3353. https://doi.org/10.3168/ jds.2008-1977.

Randall, L. V., M. J. Green, M. G. G. Chagunda, C. Mason, S. C. Archer, L. E. Green, and J. N. Huxley. 2015. Low body condition predisposes cattle to lameness: An 8-year study of one dairy herd. J. Dairy Sci. 98:3766-3777. https://doi.org/10.3168/jds.2014-8863.

Salfer, J. A., K. Minegishi, W. Lazarus, E. Berning, and M. I. Endres. 2017. Finances and returns for robotic dairies. J. Dairy Sci. 100:7739-7749. https://doi.org/10.3168/jds.2016-11976.

Schirmann, K., M. A. G. von Keyserlingk, D. M. Weary, D. M. Veira, and W. Heuwieser. 2009. Technical note: Validation of a system for monitoring rumination in dairy cows. J. Dairy Sci. 92:6052-6055. https://doi.org/10.3168/jds.2009-2361.

Tatone, E. H., T. F. Duffield, S. J. LeBlanc, T. J. DeVries, and J. L. Gordon. 2017. Investigating the within-herd prevalence and risk factors for ketosis in dairy cattle in Ontario as diagnosed by the test-day concentration of $\beta$-hydroxybutyrate in milk. J. Dairy Sci. 100:1308-1318. https://doi.org/10.3168/jds.2016-11453.

Tremblay, M., J. P. Hess, B. M. Christenson, K. K. McIntyre, B. Smink, A. J. van der Kamp, L. G. de Jong, and D. Dopfer. 2016. Factors associated with increased milk production for automatic milking systems. J. Dairy Sci. 99:3824-3837. https://doi.org/10 $.3168 /$ jds.2015-10152.

Tyrrell, H. F., and J. T. Reid. 1965. Prediction of the energy value of cow's milk. J. Dairy Sci. 48:1215-1223. https://doi.org/10.3168/ jds.S0022-0302(65)88430-2.

Vijayakumar, M., J. H. Park, K. S. Ki, D. H. Lim, S. B. Kim, S. M. Park, H. Y. Jeong, B. Y. Park, and T. Kim. 2017. The effect of lactation number, stage, length, and milking frequency on milk yield in Korean Holstein dairy cows using automatic milking system. Asian-Australas. J. Anim. Sci. 30:1093-1098. https://doi.org/10 .5713 /ajas. 16.0882 .

Wagner-Storch, A. M., and R. W. Palmer. 2003. Feeding behavior, milking behavior, and milk yields of cows milked in a parlor versus an automatic milking system. J. Dairy Sci. 86:1494-1502. https:// doi.org/10.3168/jds.S0022-0302(03)73735-7.

Wildman, E. E., G. M. Jones, P. E. Wagner, R. L. Boman, H. F. Troutt Jr., and T. N. Lesch. 1982. A dairy body condition scoring system and its relationship to selected production characteristics. J. Dairy Sci. 65:495-501. https://doi.org/10.3168/jds.S0022 $-0302(82) 82223-6$

\section{ORCIDS}

M. T. M. King @ (t) hs://orcid.org/0000-0002-7562-2221

A. J. Carpenter @ https://orcid.org/0000-0002-9779-0779

T. J. DeVries (ํ) https://orcid.org/0000-0001-9364-2456 